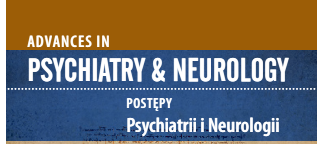

Correspondence to/

Adres do korespondencji:

Małgorzata Michałowska

Klinika Neurologii i Epileptologii

Centrum Medyczne Kształcenia

Podyplomowego

SPSK im. prof. W. Orłowskiego

ul. Czerniakowska 231

00-416 Warszawa, Polska

e-mail: mmichalowska@cmkp.edu.pl

Submitted/Otrzymano: 06.11.2017

Accepted/Przyjęto do druku: 20.03.2018

\section{NON-MOTOR SYMPTOMS ARE MORE FREQUENT IN WOMEN THAN IN MEN WITH PARKINSON'S DISEASE} CZĘSTSZE WYSTĘPOWANIE OBJAWÓW
POZARUCHOWYCH U KOBIET NIŻ
U MĘŻCZYZN Z CHOROBĄ PARKINSONA

\author{
Małgorzała Michałowska, Tomasz Szatanowski, \\ Urszula Fiszer
}

Department of Neurology and Epileptology, Centre of Postgraduate Medical Education, Warsaw, Poland

Klinika Neurologii i Epileptologii, Centrum Medyczne Kształcenia Podyplomowego, Warszawa, Polska

\begin{abstract}
Purpose: Sex differences in Parkinson's disease (PD) still remain poorly understood. The aim of our study was to examine potential sex differences in specific domains of PD clinical picture: clinical subtype of the disease, motor status, severity of dyskinesia and motor fluctuations, occurrence of gastrointestinal disturbances (anorexia, nausea, vomiting), sleep disturbance and orthostatic hypotension.

Methods: Seventy six PD patients (40 women and $36 \mathrm{men}$ ) on antiparkinsonian treatment were included. The levodopa equivalent daily dose (LEDD) was calculated. The motor symptoms severity was evaluated using the Unified Parkinson's Disease Rating Scale (UPDRS) part III and complications of therapy - using UPDRS IV A (dyskinesia), B (motor fluctuations), C (other complications, i.e. anorexia, nausea, vomiting, sleep disturbance, symptomatic orthostasis).

Results: No sex related differences were found regarding age, age of PD onset, PD duration, UPDRS III, IVA and IVB scores, LEDD, duration of levodopa and dopamine agonist treatments, the predominant symptom at PD onset and the clinical PD subtype. UPDRS IVC score were significantly higher in women than in men $(0.67 v s 0.26, p<0.05)$ and women showed a higher frequency of gastrointestinal disturbances (anorexia, nausea, vomiting), sleep disturbance and symptomatic orthostasis.

Conclusions: Our study evidenced that female PD patients on dopaminergic treatment are at higher risk of certain non-motor symptoms (NMS) than male. Further research is needed to evaluate the influence of male or female sex on various NMS and use of dopaminergic medication in different PD stage.
\end{abstract}

Key words: Parkinson's disease, sex differences, non-motor symptoms.

\title{
Streszczenie
}

Cel: Różnice zależne od płci w przebiegu choroby Parkinsona (ChP) pozostają wciąż nie do końca poznane. Celem naszego badania była ocena wpływu płci na obraz kliniczny ChP w zakresie klinicznych podtypów choroby, nasilenia objawów ruchowych, dyskinez i fluktuacji ruchowych oraz występowania zaburzeń czynności przewodu pokarmowego (jadłowstręt, nudności, wymioty), zaburzeń snu i ortostatycznych spadków ciśnienia tętniczego.

Metody: Do badania włączono 76 osób (40 kobiet i 36 mężczyzn) z rozpoznaną ChP i leczonych lekami przeciwparkinsonowskimi. U każdego pacjenta obliczono równoważną dobową dawkę lewodopy. Nasilenie objawów ruchowych oceniono przy użyciu skali UPDRS III, zaś objawów niepożądanych leczenia - przy użyciu UPDRS IVA (dyskinezy), IVB (fluktuacje ruchowe), IVC (inne powikłania: jadłowstręt, nudności, wymioty, zaburzenia snu, ortostatyczne spadki ciśnienia).

Wynki: Kobiety i mężczyźni nie różnili się pod względem wieku, wieku zachorowania na ChP, czasu trwania choroby, punktacji uzyskanej w skalach III, IVA i IVB, przyjmowanej równoważnej dobowej dawki lewodopy, czasu trwania leczenia lewodopą i agonistą dopaminergicznym, przeważającego objawu w momencie zachorowania na ChP ani podtypu klinicznego choroby. Kobiety uzyskały znamiennie wyższą punktację w skali UPDRS IVC w porównaniu z mężczyznami $(0,67 v s \quad 0,26 ; p<0,05)$ i u kobiet zaburzenia czynności przewodu pokarmowego (jadłowstręt, nudności, wymioty), zaburzenia snu i ortostatyczne spadki ciśnienia tętniczego występowały częściej. 
Non-motor symptoms are more frequent in women than in men with Parkinson's disease

Częstsze występowanie objawów pozaruchowych u kobiet niż u mężczyzn z chorobą Parkinsona

Wnioski: Wyniki wskazują, że u kobiet chorujących na ChP i leczonych lekami dopaminergicznymi istnieje wyższe ryzyko wystąpienia określonych objawów pozaruchowych niż u mężczyzn. Ocena wpływu płci na objawy pozaruchowe i przyjmowanie leków dopaminergicznych w różnych stadiach zaawansowania ChP wymaga jednak dalszych badań.

Słowa kluczowe: choroba Parkinsona, różnice zależne od płci, objawy pozaruchowe.

\section{PURPOSE}

Sex-specific genetic and hormonal factors may have implications for expression of neurodegenerative disorders, including Parkinson's disease (PD). Epidemiological studies show that overall incidence and prevalence of PD is 1.5 times higher in men than in women [1-3] and several studies suggest that men also have an earlier age of PD onset, faster rate of disease progression and increased mortality risk than women, whilst women have more benign phenotype in early PD but higher risk for motor (wearing-off and dyskinesia) and non-motor (especially mood-related fluctuations) levodopa induced complications [4-9]. Then male sex seems to be a risk factor in development of cognitive impairment and dementia in PD [10]. Sex differences in other non-motor symptoms (NMS) are probably more complex; studies on this subject matter have not always reported consistent findings, however, the recent study suggest that PD men are at higher risk of several NMS [11]. Sex related differences in PD still remain poorly understood. The aim of our study was to examine potential sex differences in specific domains of PD clinical picture: clinical subtype of the disease, motor status, severity of dyskinesia and motor fluctuations, occurrence of gastrointestinal disturbances (anorexia, nausea, vomiting), sleep disturbance and orthostatic hypotension.

\section{METHODS}

Seventy six patients (40 women and 36 men) with idiopathic PD diagnosed in conformity with the United Kingdom PD Society Brain Bank, the European Federation of Neurological Societies and the International Parkinson and Movement Disorder Society's European Section recommendations $[12,13]$ were included. The recruitment process was based on consecutive entrance to the outpatient clinic of the Department of Neurology and Epileptology, Centre of Postgraduate Medical Education, Warsaw (Poland). The local ethics committee approved this study and all patients provided informed consent according to the Declaration of Helsinki.

Patients were treated as follows: 1 ) levodopa and ropinirole - 33 (43.4\%) patients, 2) levodopa monotherapy 19 (25\%) patients, 3) levodopa and piribedil - 8 (10.5\%) patients, 4) levodopa and ropinirole and entacapone -
$6(7.9 \%)$ patients, 5) levodopa and ropinirole and amantadine - 3 (4\%) patients, 6) levodopa and piribedil and amantadine - 3 (4\%) patients, 7) levodopa and amantadine - 2 (2.6\%) patients, 8 ) levodopa and entacapone and amantadine - $1(1.3 \%)$ patient, 9$)$ levodopa and ropinirole and entacapone and amantadine - $1(1.3 \%)$ patient. The levodopa equivalent daily dose (LEDD) was calculated [14]. Neither of the patients underwent stereotactic surgery.

The motor symptoms severity was evaluated using the Unified Parkinson's Disease Rating Scale (UPDRS) part III (in on phase) and complications of therapy using UPDRS IV (A: dyskinesia, B: motor fluctuations, C: other complications, i.e. anorexia, nausea, vomiting, sleep disturbance, symptomatic orthostasis) [15]. The characteristics of the group are presented in table 1.

Patients were classified according to van Rooden's et al. [16] clinical PD subtypes definition. The authors identified 4 subtypes characterised by differences in the severity of nondopaminergic features and motor complications: subtype 1 is mildly affected in all domains, subtype 2 is predominantly characterised by severe motor complications, subtype 3 is affected mainly on nondopaminergic features without prominent motor complications and subtype 4 is severely affected in all domains.

Women and men were compared with respect to age, age of PD onset, PD duration, UPDRS III and IV (A, B, C) scores, LEDD, duration of levodopa and dopamine agonist treatments using Mann-Whitney test and to the predominant symptom (tremor, hypertonia or akinesia) at PD onset and clinical PD subtype using $\chi^{2}$ Pearson test. The level of statistical significance was set at $p<0.05$.

\section{RESULTS}

PD started with predominant tremor in $48(63 \%)$ patients, with predominant hypertonia in $21(28 \%)$ patients and with predominant akinesia in 7 (9\%) patients. Subtype 1 of PD according to van Rooden's et al. classification (2011) was found in $41(54 \%)$ patients, subtype 2 - in 28 (37\%), subtype 3 - in $2(2.5 \%)$ and subtype 4 - in 5 (6.5\%) patients.

Differences between women and men are showed in table 2. No differences were found in age, age of PD onset, PD duration, UPDRS III scores, UPDRS IVA and IVB scores, LEDD, duration of levodopa treatment, duration of dopamine agonist treatment, the predominant 
Table 1. Patients' characteristics

\begin{tabular}{|c|c|c|c|}
\hline & Mean & Range & SD \\
\hline Age (years) & 65.70 & $41-88$ & 9.33 \\
\hline Age at PD onset (years) & 55.37 & $32-72$ & 8.85 \\
\hline PD duration (years) & 10.33 & $3-23$ & 4.56 \\
\hline Duration of levodopa treatment (years) & 8.65 & $1-20$ & 4.35 \\
\hline Duration of dopamine agonist treatment (years) & 4.10 & $0,5-12$ & 2.60 \\
\hline Daily levodopa dose $(\mathrm{mg})$ & 763.82 & $200-2550$ & 379.24 \\
\hline Levodopa equivalent daily dose (LEDD) (mg) & 825.07 & $200-2500$ & 385.47 \\
\hline
\end{tabular}

Table 2. Differences between females and males PD patients

\begin{tabular}{|c|c|c|c|c|c|}
\hline & \multicolumn{2}{|c|}{ Females } & \multicolumn{2}{|c|}{ Males } & \multirow{3}{*}{$p$ value } \\
\hline \multirow[t]{2}{*}{ Number of patients } & \multicolumn{2}{|c|}{40} & \multicolumn{2}{|c|}{36} & \\
\hline & Mean \pm SD & Range & Mean \pm SD & Range & \\
\hline Age & $67.15 \pm 9.43$ & $47-88$ & $64.08 \pm 9.08$ & $41-83$ & ns \\
\hline Age at PD onset & $57.67 \pm 8.39$ & $35-72$ & $54.63 \pm 8.82$ & $32-74$ & ns \\
\hline PD duration & $10.53 \pm 4.56$ & $3-23$ & $10.11 \pm 4.62$ & $3-23$ & ns \\
\hline UPDRS III score & $19.51 \pm 10.16$ & $4-43$ & $18.24 \pm 8.99$ & $3-38$ & ns \\
\hline UPDRS IV A score & $1.69 \pm 2.52$ & $0-9$ & $0.76 \pm 1.30$ & $0-5$ & ns \\
\hline UPDRS IV B score & $1.95 \pm 1.82$ & $0-5$ & $1.71 \pm 1.73$ & $0-5$ & ns \\
\hline UPDRS IV C score & $0.67 \pm 0.87$ & $0-3$ & $0.26 \pm 0.51$ & $0-2$ & $p=0.039$ \\
\hline LEDD & $776.00 \pm 355.38$ & $200-1750$ & $879.58 \pm 414.57$ & $215-2250$ & ns \\
\hline Duration of levodopa treatment & $8.85 \pm 4.71$ & $1-20$ & $8.41 \pm 3.97$ & $3-18$ & ns \\
\hline Duration of dopamine agonist treatment & $3.97 \pm 2.32$ & $0-10$ & $4.25 \pm 2.69$ & $1-12$ & ns \\
\hline Predominant symptom at PD onset: & \multicolumn{2}{|c|}{ Number } & \multicolumn{2}{|c|}{ Number } & - \\
\hline Tremor & \multicolumn{2}{|c|}{25} & \multicolumn{2}{|c|}{23} & \multirow{3}{*}{$\mathrm{ns}^{*}$} \\
\hline Hypertonia & \multicolumn{2}{|c|}{11} & \multicolumn{2}{|c|}{10} & \\
\hline Akinesia & \multicolumn{2}{|c|}{4} & \multicolumn{2}{|c|}{3} & \\
\hline Clinical PD subtype & \multicolumn{2}{|c|}{ Number } & \multicolumn{2}{|c|}{ Number } & - \\
\hline Subtype 1 & \multicolumn{2}{|c|}{21} & \multicolumn{2}{|c|}{20} & \multirow{2}{*}{$n s^{*}$} \\
\hline Subtype 2 & \multicolumn{2}{|c|}{13} & \multicolumn{2}{|c|}{15} & \\
\hline
\end{tabular}

ns - non significant

nothing - Mann-Whitney test

* Chi' Pearson test

symptom at PD onset and the clinical PD subtype 1 and 2 between women and men. The difference in clinical PD subtype 3 and 4 was not considered because of low number of patients in these groups. Women and men showed differences in UPDRS IVC scores (0.67 versus 0.26 , $p<0.05)$. Anorexia, nausea, vomiting occurred in $4(10.0 \%)$ women, occurred in no men. Sleep disturbance and symptomatic orthostasis also were more frequent in women, respectively in $16(40.0 \%)$ women versus $8(22.2 \%)$ men and $6(15.0 \%)$ versus $4(11.1 \%)$ (Figure 1$)$.

\section{DISCUSSION}

In our study, female and male PD patients presented comparable motor status, dyskinesia and motor fluctu- ations, and had comparable occurrence of clinical PD subtype 1 (mildly affected in nondopaminergic features and motor complications) and subtype 2 (predominantly severe motor complications) according to van Rooden's et al. [16] classification. Women and men were also similar in LEDD and duration of dopaminergic treatment. Until now, few studies have examined sex influences on use of dopaminergic therapy in PD. No sex differences were found in the type and dose of dopaminergic medications used in early PD [17] as well as in clinical manifestations and prognosis under the same treatment conditions [18].

Little is known about sex-related differences in anorexia, nausea, vomiting and orthostatic hypotension in PD. In our study involving PD patients on dopaminergic treatment women (as compared with men) showed 

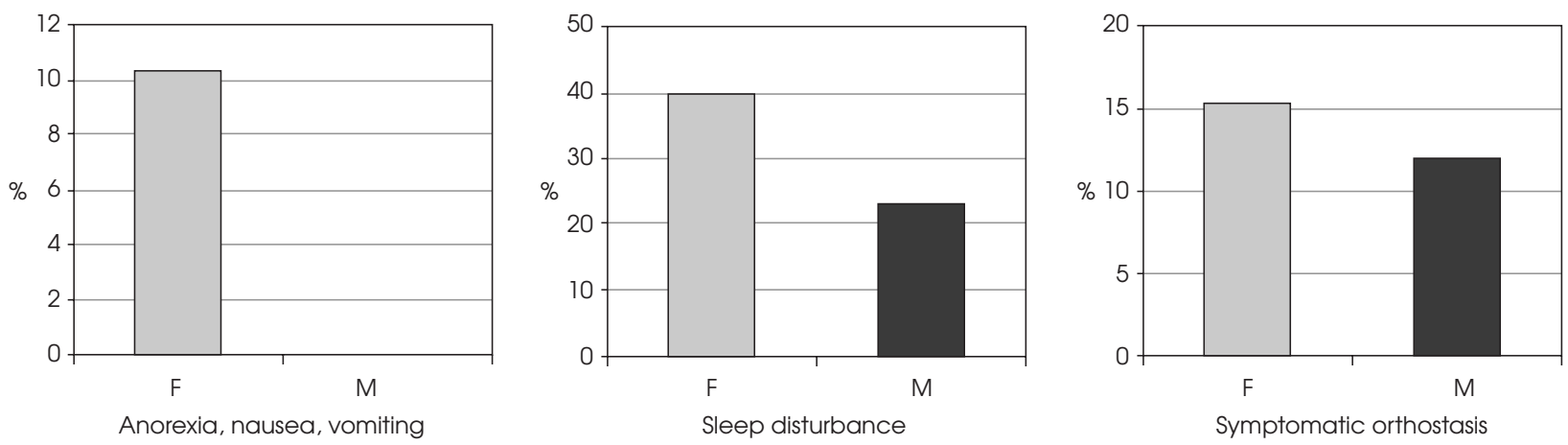

Figure 1. Differences in occurrence of features scored in UPDRS IVC between women (F) and men (M) (percentages of patients in the same sex group)

a significantly higher scores in UPDRS IVC with a higher frequency of gastrointestinal disturbances (anorexia, nausea, vomiting), sleep disturbance and symptomatic orthostasis. Non-motor symptoms may be affected by both antiparkinsonian treatment and neurodegenerative process, and it is difficult to differentiate their influence. The number and severity of NMS were clearly higher in untreated de novo diagnosed PD patients comparing to control population [19]; yet, among drug-naïve patients with early PD, olfactory and sex disturbances seemed to be more severe in men than in women $[20,21]$, and men reported more pronounced certain cognitive deficits, whereas women experienced higher anxiety [21]. In PD patients, predominantly $(87.8 \%)$ on antiparkinsonian treatment, without comparison with the general population, a higher prevalence or severity of fatigue, anxiety and pain were found in women, whereas sexual dysfunction was more prevalent in men [22]. Nicoletti et al. [11] also included PD patients predominantly $(93.8 \%)$ on antiparkinsonian treatment, nonetheless in the case-control study, and reported that women showed a significantly higher frequency of depression and urinary disturbance than men. However, with respect to the control population and according to logistic regression stratified by sex and adjusted by age, the presence of depression, sleep disturbance, hallucination and cognitive impairment on the bases of the MMSE was stronger associated with PD in men and the presence of urinary disturbance in women [11]. Hypersexuality was associated with men and higher doses of dopamine agonists [23].

\section{CONCLUSIONS}

1. Our study evidenced that female PD patients on dopaminergic treatment are at higher risk of certain NMS (anorexia, nausea, vomiting, sleep disturbance and symptomatic orthostasis) than male ones.

2. Further research is needed to evaluate the influence of male or female sex on various NMS and use of dopaminergic medication in different PD stage, but sex-delineated clinical assessment and potential differences must already be considered in the clinical management of PD.

\section{Conflict of interest/Konflikt interesu}

Absent./Nie występuje.

Financial support/Finansowanie

Absent./Nie występuje.

References/Piśmiennicłwo

1. Taylor KSM, Cook JA, Counsell CE. Heterogeneity in male to female risk for Parkinson's disease. J Neurol Neurosurg Psychiatry 2007; 78: 905-912.

2. Moisan F, Kab S, Mohamed F, Canonico M, Le Guern M, Quintin C, et al. Parkinson disease male-to-female ratios increase with age: French nationwide study and meta-analysis. J Neurol Neurosurg Psychiatry 2015; 87: 952-957. 
3. Picillo M, Nicoletti A, Fetoni V, Garavaglia B, Barone P, Pellecchia MT. The relevance of gender in Parkinson's disease: a review. J Neurol 2017; 264(8): 1583-1607.

4. Zappia M, Annesi G, Nicoletti G, Arabia G, Annesi F, Messina D, et al. Sex differences in clinical and genetic determinants of levodopa peak-dose dyskinesias in Parkinson disease: an exploratory study. Arch Neurol 2005; 62(4): 601-605.

5. Haaxma CA, Bloem BR, Borm GF, Oyen WJ, Leenders KL, Eshuis S, et al. Gender differences in Parkinson's disease. J Neurol Neurosurg Psychiatry 2007; 78(8): 819-824.

6. De Lau LML, Verbaan D, Marinus J, van Hilten JJ. Survival in Parkinson's disease. Relation with motor and non-motor features. Parkinsonism Relat Disord 2014; 20(6): 613-616.

7. Lubomski M, Louise Rushworth R, Lee W, Bertram KL, Williams DR. Sex differences in Parkinson's disease. J Clin Neurosci 2014; 21(9): 1503-1506.

8. Bjornestad A, Forsaa EB, Pedersen KF, Tysnes OB, Larsen JP, Alves G. Risk and course of motor complications in a population-based incident Parkinson's disease cohort. Parkinsonism Relat Disord 2016; 22: 48-53.

9. Picillo M, Palladino R, Moccia M, Erro R, Amboni M, Vitale C, et al. Gender and non motor fluctuations in Parkinson's disease: a prospective study. Parkinsonism Relat Disord 2016; 27: 89-92.

10. Cereda E, Cilia R, Klersy C, Siri C, Pozzi B, Reali E, et al. Dementia in Parkinson's disease: is male gender a risk factor? Parkinsonism Relat Disord 2016; 26: 67-72.

11. Nicoletti A, Vasta R, Mostile G, Nicoletti G, Arabia G, Iliceto G, et al. Gender effect on non-motor symptoms in Parkinson's disease: are men more at risk? Parkinsonism Relat Disord 2017; 35: 69-74.

12. Hughes AJ, Daniel SE, Kilford L, Lees AJ. Accuracy of clinical diagnosis of idiopathic Parkinson's disease: a clinicopathological study of 100 cases. J Neurol Neurosurg Psychiatry 1992; 55(3): 181-184.

13. Berardelli A, Wenning GK, Antonini A, Berg D, Bloem BR, Bonifati V, et al. EFNS/MDS-ES recommendations for diagnosis of Parkinson's disease. Eur J Neurol 2013; 20(2): 16-34.

14. Tomlinson CL, Stowe R, Patel S, Rick C, Gray R, Clarke CE. Systematic review of levodopa dose equivalency in Parkinson's disease. Mov Disord 2010; 25(15): 2649-2653.

15. Fahn S, Elton RL. Unified Parkinson's Disease Rating Scale. In: Fahn S, Mardsen CD, Calne DB, et al. (eds). Recent Developments in Parkinson's Disease. Florhan Park, NJ: Mac Millan Health Care Information; 1987; 153-163.

16. van Rooden SM, Colas F, Martínez-Martín P, Visser M, Verbaan D, Marinus J, et al. Clinical subtypes of Parkinson's disease. Mov Disord 2011; 26(1): 51-58.

17. Umeh CC, Pérez A, Augustine EF, Dhall R, Dewey RB Jr, Mari Z, et al. No sex differences in use of dopaminergic medication in early Parkinson disease in the US and Canada - baseline findings of a multicenter trial. PloS One 2014; 9(12): e112287.

18. Dahodwala N, Pei Q, Schmidt P. Sex differences in the clinical progression of Parkinson's disease. J Obstet Neonatal Nurs 2016; 45: 749-756.

19. Bago Rožanković P, Rožanković M, Vučak Novosel L, Stojić M. Nonmotor symptoms in de novo Parkinson disease comparing to normal aging. Clin Neurol Neurosurg 2017; 155: 7-11.

20. Picillo M, Amboni M, Erro R, Longo K, Vitale C, Moccia M, et al. Gender differences in nonmotor symptoms in early, drug naive Parkinson's disease. J Neurol 2013; 260(11): 2849-2855.

21. Liu R, Umbach DM, Peddada SD, Xu Z, Tröster AI, Huang X, Chen H. Potential sex differences in non-motor symptoms in early drug-naive Parkinson disease. Neurology 2015; 84(21): 2107-2115.

22. Martinez-Martin P, Falup Pecurariu C, Odin P, van Hilten JJ, Antonini A, Rojo-Abuin JM, et al. Gender-related differences in the burden of non-motor symptoms in Parkinson's disease. J Neurol 2012; 259(8): 1639-1647.

23. Nakum S, Cavanna AE. The prevalence and clinical characteristics of hypersexuality in patients with Parkinson's disease following dopaminergic therapy: a systematic literature review. Parkinsonism Relat Disord 2016; 25: 10-16. 